\title{
Euskadin etxez etxeko laguntzaren esleipenari eta intentsitateari buruz orientabidea eskaintzeko tresnaren garapena
}

\author{
SIIS Dokumentazio eta Ikerketa Zentroa \\ Eguía-Careaga Fundazioa \\ <estudios@siis.net>
}

\begin{abstract}
Artikulu honetan, SIIS Dokumentazio eta Ikerketa Zentroak, Eudel-en eskariari erantzunez, EAEn etxez etxeko laguntza-zerbitzu publikoaren esleipena arautuko duen tresna bat garatu eta balioztatzeko buruturiko ikerketa baten berri ematen da. Tresna horren helburua zerbitzuaren esleipena irizpide objektiboetan oinarritzea litzateke; horrela, tresna EAEko udalerri guztietan ezarriko balitz, baliabide publiko mugatuen erabilera arrazionalagoa egingo litzateke, eta zerbitzurako sarbidea eta haren intentsitatea berdinduko lirateke, EAEko lurralde osoan. Hala eta guztiz ere, irakurleak jakin behar du, artikulu honetan aurkezten dena proiektu pilotu bat dela eta, ondorioz, ez dakigula, azkenik, tresna EAE osoan ezartzea erabakiko ote den. Erabaki hori, etxez etxeko laguntza-zerbitzuaren eskumena duten administrazioei dagokie eta, era berean, EAEko Gizarte Zerbitzuen Sistemako Prestazioen eta Zerbitzuen Karteraren garapenaren inguruan adosturikoaren menpe dago. Artikuluan, proiektuaren beharra eta egokitasuna arrazoitu ondoren, berau aurrera eramateko metodologia zein izan den azaltzen da, eta aukeraturiko tresnaren baliagarritasunari buruz ikerketaren fase praktikoan parte hartu duten hamar udalerrietan lorturiko emaitzak laburbiltzen dira.
\end{abstract}

\section{HITZ-GAKOAK:}

etxez etxeko laguntza-zerbitzua, beharren balorazioa, balorazio-tresna teknikoak, sarbidea, intensitatea.
En este artículo se da cuenta de una investigación llevada a cabo por el SIIS Centro de Documentación y Estudios, a petición de Eudel, con el objetivo de diseñar y validar un instrumento técnico para regular el acceso al servicio público de ayuda a domicilio en la CAPV. La finalidad de este instrumento es que la adjudicación del servicio se base en criterios objetivos, de manera que se consiga hacer un uso más racional de los recursos públicos y se eliminen las desigualdades existentes en el territorio en cuanto al acceso y a la intensidad del servicio. Con todo, ha de tenerse en cuenta que se trata de un proyecto piloto y, por el momento se desconoce si finalmente se optará por implantar el instrumento en todos los municipios de la CAPV. Esa decisión, que corresponde a las administraciones competentes en materia de ayuda a domicilio, está también condicionada por las decisiones que se adopten en el marco del desarrollo de la Cartera de Prestaciones y Servicios del Sistema Vasco de Servicios Sociales. Tras justificar la necesidad y pertinencia del proyecto, el artículo expone la metodología utilizada para llevarlo a cabo y recoge los principales resultados sobre la validez del instrumento que se han obtenido en los diez ayuntamientos vascos que han participado en el proyecto piloto.

\section{Palabras Clave:}

servicio de ayuda a domicilio, valoración de necesidades, instrumentos técnicos, acceso, intensidad. 


\section{Sarrera}

Etxez etxeko laguntza-zerbitzua da, gaur egun, menpekotasun-egoeran diren pertsonak -edo menpekotasuna pairatzeko arriskuan direnakeuren ingurunean mantentzeko erakunde publikoek eskaintzen duten zerbitzu garrantzitsuena. Honen bitartez, eguneroko zereginetarako laguntza behar duten pertsonei euren etxean eskaintzen zaie laguntza hori; horrela, egoitza-zerbitzuetara jo beharra ekiditen dute, edo momentu hori atzeratzea lortzen dute, behintzat. Garrantzi handiko zerbitzua dela esan daiteke, beraz, izaera prebentiboa duelako, lehenik eta behin, baina baita erabiltzaile multzo handia asetzen duen zerbitzua delako ere: Eustaten Gizarte-Zerbitzuetako Erakunde eta Zentroen Estatistikaren arabera, 2008an 26.500 erabiltzaile inguru izan zituen zerbitzuak, eta ia 78 milioi euroko gastua suposatu zuen euskal administrazioentzat.

Laguntza-beharra duten pertsonek Oinarrizko Gizarte Zerbitzuetan egiten dute etxez etxeko zerbitzuaren eskaera, eta, EAEko gizarte-zerbitzuak arautzen dituen abenduaren 5eko 12/2008 Legearen arabera, tokian tokiko administrazioei dagokie eskaera horiek ebaztea. Oraindik orain, udal bakoitzak ezartzen ditu ebazpen horiek egiteko irizpideak eta, ondorioz, desberdintasun nabarmenak ematen dira zerbitzurako sarbidean, eskaera egiten duen pertsonaren bizilekuaren arabera. Esate baterako, aipatutako estatistikaren arabera, 2008an, Araban, zerbitzuaren estaldura (12,3 erabiltzaile 1.000 biztanleko) Gipuzkoakoaren bikoitza izan zen, eta Bizkaiko zerbitzuek eskaini zuten batez besteko intentsitatea, berriz -batez beste astean bi ordu erabiltzaile bakoitzeko-, ez zen iritsi beste bi lurraldeetakoek ematen zutenaren erdia izatera ere.

2007 urtea ezkero, abenduaren 14ko 39/2006 Legeak, Autonomia Pertsonala eta Menpekotasun Egoeran Diren Pertsonen Arretari buruzkoak, etxez etxeko laguntza eta gainontzeko gizartezerbitzuetarako sarbidea arautu du menpekotasun egoeran diren pertsonentzat, balizko erabiltzaileen beharrak neurtzeko Menpekotasuna Baloratzeko Baremoaren (Baremo de Valoración de la Dependencia) erabilera ezarri du-eta. Hala ere, pertsona autonomoen edo menpekotasun arina dutenen kasuan, zerbitzurako sarbidea udal bakoitzaren -eta, azken batean, Oinarrizko Gizarte Zerbitzuetako profesional bakoitzaren- esku dago. Zerbitzuaren intentsitatea ere profesional bakoitzak erabakitzen du -gehieneko kopuru batzuk errespetatuz, noski-, eta haren egokitasuna norberaren trebetasuna eta esperientziaren araberakoa da, beraz, neurri batean. Ikerketa garaian buruturiko bilaketa dokumentalaren emaitzen arabera, EAEko Oinarrizko Gizarte Zerbitzuetan ez da erabiltzen inolako tresna teknikorik eskaintzen den intentsitatea pertsonaren beharrak betetzeko egokia dela bermatzeko.

Egoera hori bideratze aldera, abenduaren 5eko 12/2008 Legeak, Gizarte Zerbitzuei buruzkoak, EAEko biztanleoi gizarte-zerbitzuak jasotzeko eskubidea
1. grafikoa. Etxez etxeko laguntza zerbitzuaren estaldura eta intentsitatea, lurraldeka. EAE, 2008

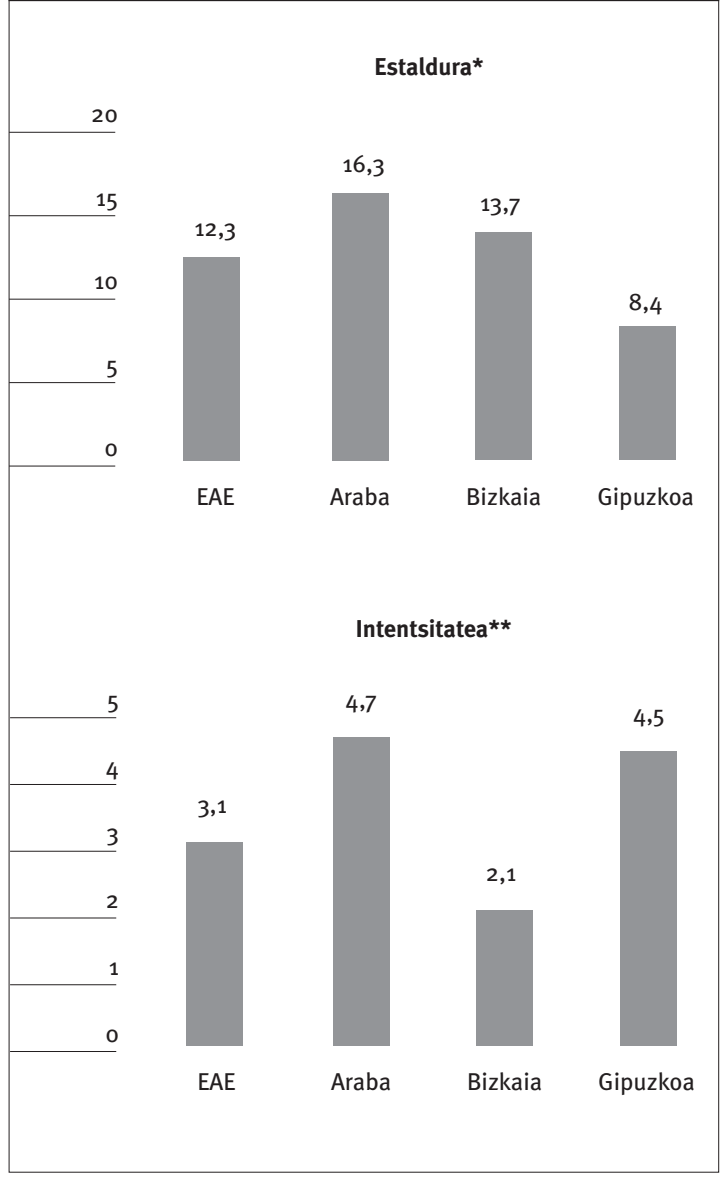

* Erabiltzaile kopurua 1.000 biztanleko.

** Asteko arreta-ordu kopurua erabiltzaile bakoitzeko.

Iturria: Eustaten Gizarte-Zerbitzuetako Erakunde eta Zentroen Estatistikatik moldeatua.

onartzearekin batera, eskubide horien hartzaile izango direnen beharrak neurtzeko tresna tekniko egokiak sortuko direla zehaztu du. Testuinguru honetan, EAEko udalek aukera ikusi dute, ahal den neurrian, irizpide objektibo bateratuetan oinarrituriko tresna bat erabiltzeko, etxez etxeko laguntzazerbitzua esleitu eta haren intentsitatea ezartzeari begira. Horrelako ekimen baten beharra nabarmena da, ondoko arrazoiengatik:

- Justiziari eta berdintasunari begira, lehenik eta behin, alegia, herritar guztiek zerbitzua jasotzeko aukera berberak izan ditzaten. Berdintasuna, kasu honetan, beharren araberako erantzuna ematea izango litzateke, hau da, antzeko beharrei antzeko erantzuna ematea EAEko udalerri guztietan.

- Baita zerbitzua eraginkorrago izan dadin ere; hau da, ahalik eta beharrean diren pertsona gehien artatzeko eta, aldi berean, zerbitzurik gabe ere ondo molda daitezkeenei ematea ekiditeko. Eraginkortasunaren gaia beti ere garrantzitsua den arren, are ardurazkoago da gaurkoa bezalako krisi 
2. grafikoa. Menpekotasuna duten pertsonentzako zerbitzuetan egiten den gastua, helburuaren arabera. EAE, $2009(\%)$
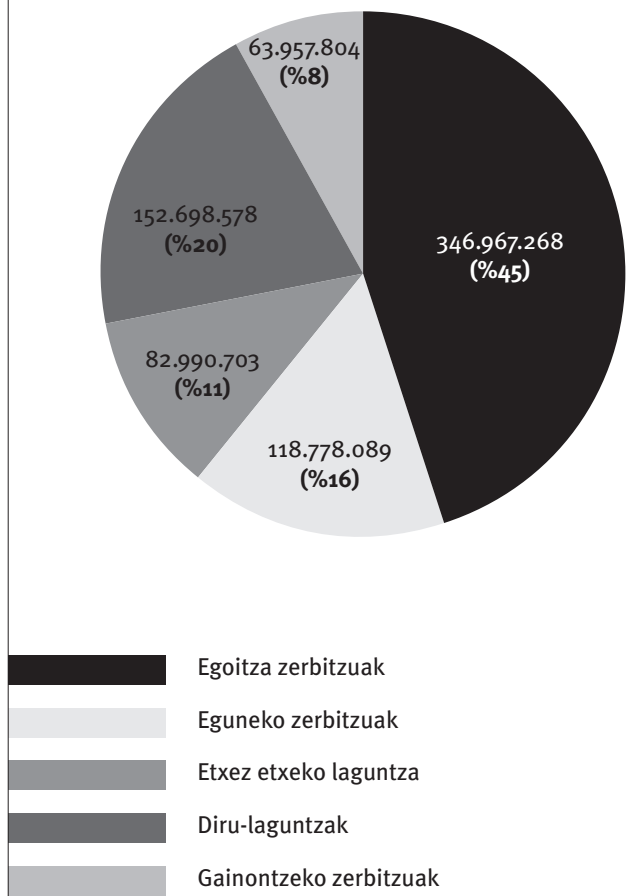

Iturria: Eusko Jaurlaritzaren gizarte zerbitzuetako gastu publikoari buruzko ikerketatik moldatua.

garaietan; batez ere, jakinik, gaur egun, Euskadin, menpekotasun-egoeran diren pertsonentzako zerbitzuetan gastatzen diren hamar eurotik bat etxez etxeko laguntza-zerbitzua ordaintzeko erabiltzen dela.

Horrela, aipatutako helburuak lortu eta, etxez etxeko laguntza jasotzeari dagokionez, EAEko udalen artean ematen diren desberdintasunekin amaitzeko asmoz, 2009ko irailean, Euskal Udalen Elkarteak (Eudel) erabaki zuen Oinarrizko Gizarte Zerbitzuetako langileei orientabidea eskaintzeko tresna garatzea. Tresna horren helburua, aurrerantzean zerbitzuaren balizko erabiltzaileen beharrak objektiboki neurtu eta, balorazio horretan oinarrituz, zerbitzuaren esleipena eta intentsitateari buruzko orientabidea eskaintzea izango da.

Proiektu hau aurrera eramateko, SIIS Dokumentazio eta Ikerketa Zentroarekin (aurrerantzean SIIS) harremanetan jarri zen Eudel. Hortik aurrera, SIISek, EAEko zerbitzuei egokituriko tresna aukeratu edo garatzeko, eta berau balioztatzeko metodologia proposatu zuen. Txosten honen hurrengo ataletan, metodologia hori azalduko da, garaturiko tresnak deskribatuko dira, eta balioztapen ikerketan jaso diren emaitzak ezagutzera emango dira.

\section{Metodologia}

Eudelekin adostutako proiektua hiru fasetan garatu da. Lehen fasean, 2009ko iraila eta 2010-eko urtarrila bitartean, ikerketa bat burutu da etxez etxeko laguntza-zerbitzua esleitzeko orduan erabili beharreko irizpideak ezartzeko, eta irizpide horiek kontuan izango dituen tresna aurkitu edo garatzeko. Bigarren fasean, 2010eko otsaila eta 2011ko otsaila bitartean, aukeraturiko tresna balioztatze-prozesuan izan da. Prozesu horretan, EAEko hamar udalen lankidetza izan dute Eudel eta SIISek. Proiektuaren hirugarren fasean ${ }^{1}$, balioztaturiko tresna Eudelen eta EAEko oinarrizko gizarte-langileen esku ipiniko da eta urte betez erabileraren jarraipena egingo dela aurreikusi da.

\subsection{Tresnaren diseinu-fasea}

Proiektuaren lehen fasean, gurean erabiltzeko tresna egokia aurkitu edo garatzeari begira, etxez etxeko zerbitzuaren inguruko bibliografia bildu eta aztertu da, eta Europako hainbat aditurekin harremanetan jarri da SIIS. Informazio-bilketa horren helburu zehatzak honakoak izan dira:

- Ezagutzea, gurean baino gizarte-politika aurreratuagoak dituzten herrialdeetan, etxez etxeko laguntza-zerbitzua jasotzeko irizpideak zeintzuk diren, nork ezartzen dituen eta nola.

- Herrialde horietan, balizko erabiltzaileen beharrak neurtzeko inolako tresnarik erabiltzen ote duten jakitea.

- Helburu bera edo antzekoa izan dezaketen tresna balioztatuak biltzea.

- Etxez etxeko zerbitzuaren behar objektiboarekin lotura duten faktoreen inguruko ezagutza zientifikoa biltzea, aurkituriko tresnak kritikoki baloratu eta egokiena aukeratzeko edo, hala behar izatekotan, tresna EAErako espresuki garatzeko.

Bilaketa dokumentala egiteko, SIISeko datu-base bibliografikoa ${ }^{2}$ erabili da. Gaiari buruzko dokumentuak aurkitzeko atención domiciliaria, asistencia domiciliaria, valoración de necesidades, eta instrumentos técnicos bilaketa-hitzak erabili dira eta, aurkituriko erreferentzien artean, etxez etxeko zerbitzua esleitzeko irizpideei eta zerbitzuen intentsitatea ezartzeko tresnei buruzko informazioa eskaintzen zuten dokumentuak aukeratu dira. Etxez etxeko zerbitzuari bereziki zegozkion dokumentuak oso urriak zirela ikusirik, bilaketa zabaldu egin da, gainontzeko zaintza-zerbitzuak esleitu eta haien intentsitatea neurtzeko tresnak aipatzen zituzten dokumentuak aintzat hartzeko.

${ }^{1}$ Hirugarren fase honen hasiera data zehazteke dago oraindik, Eudelek balioztatze-ikerketaren emaitzak aztertu bitartean.

2 SIIS Dokumentazio Zentroak 174.500 dokumentu inguruko ondarea du. Bertan aurki daitezke gizarte-politiken eta gizarte-zerbitzuen alorreko nazioarteko argitalpen nagusiak. 
Bestalde, gaiari buruzko literatura zientifikoaren berrikusketa horren bidez bildutako informazioa osatzeko, Austria, Alemania, Danimarka, Erresuma Batua, Frantzia eta Suediako zenbait adituri kontsulta egin zaie ${ }^{3}$. Aditu hauetako bakoitzari egituratutako galdetegi bat bidali zaio, honako informazioa biltzeko asmoz:

- Zeintzuk diren, aditu den herrialdean, etxez etxeko laguntza zerbitzu publikoaren ezaugarri nagusiak, antolakuntza eta finantziazioari dagokionez.

- Zerbitzua emateko irizpideak zeintzuk diren, alegia, eskaria egiten duten pertsonek zerbitzua jaso ahal izateko ze baldintza bete behar dituzten.

- Zerbitzuaren intentsitateari dagokionez, gehieneko kopururik ezartzen al den.
- Tresna teknikorik (eskala edo baremorik) erabiltzen al den erabiltzaileen beharrak neurtzeko.

Bildutako informazioa aztertu ondoren, egiaztatzezerrenda bat garatu da, proiektuaren helburuei egokituriko tresna batek izan behar lituzkeen ezaugarriak zehazten dituena. Zerrenda hau bilaketa dokumentalaren bidez antzemandako tresnen artean egokiena izan zitekeena aukeratzeko erabili da.

Bilaketa dokumentalaren bidez aurkituriko tresnak baloratzeko, ondoko irizpide-zerrenda hau garatu zen. SIIS-eko teknikarien lana izan zen aurkituriko tresna bakoitzak zerrendako irizpideak betetzen zituen ala ez zehaztea.

\section{1. koadroa. Egiaztatze zerrenda}

- Zerbitzuaren eskaera egiten duen pertsonaren autonomia-maila du irizpide nagusitzat.

- Pertsona nagusien nahiz ezintasunak dituzten pertsona gazteagoen beharrak neurtzeko balio du, euren ezintasuna dena delakoa izan (fisikoa ala psikikoa). Ez du zertan haur eta familientzako gizarte-heziketa beharrak neurtzeko aproposa izan (zerbitzu hori, zenbait udalek etxez etxeko laguntza-zerbitzuaren barne eskaintzen duten arren, aparteko zerbitzutzat jotzen da).

- Oinarrizko Gizarte Zerbitzuetan, elkarrizketa bidez aplikatzeko moduko tresna da, konplexutasuna eta luzerari dagokionez.

- Gizarte-laneko gradua duten profesionalek bete ahal izateko moduko tresna da, hau da, ez dago beharrik medikuntza edo beste alor batzuetako profesionalek parte hartzeko.

- Intentsitatea neurtzeko orduan, erabiltzailearen benetako beharrak hartzen ditu kontutan (zaintzaile formal eta informalek eskaintzen dioten laguntza alde batera utzita).

- Beharren zuzeneko neurketan oinarritzen da, ez antzeko ezaugarriak dituzten erabiltzaileei eskaintzen zaien batez besteko intentsitateari buruzko estatistiketan.

- Norberaren zaintzarekin zerikusia duten eguneroko jardueretan laguntzeko eta etxeko lanetarako beharreko denboraren artean bereizten du.

- Pertsonak euren etxean ongi zainduta mantentzeko beharrezko jarduerak kontuan hartzen ditu, eta horiek bakarrik. Baliabide publikoen gestio efizientea egiteari begira, behar-beharrezkoak ez diren jarduerak mugatzea nahitaezkotzat jotzen da.

- Gizarte-zerbitzuetan dagoeneko biltzen den informazioa aprobetxatzen du.

- Gizarte-zerbitzuetan dagoeneko erabiltzen diren tresnekin bateragarria da.

Iturria: Egilearen lana.

${ }^{3}$ Euren ekarpenak eskertu nahi dizkiegu honako pertsonei: Eigil Boll Hansen (Gobernu-Ikerketarako Institutu Daniarra [AKF], Danimarka), Vic Citarella (Gizarte-Zerbitzuetako Zuzendarien Elkartea [ADASS], Erresuma Batua), Alain Colvez (INSERM Montpellier, Frantzia), Mårten Lagergren (Äldrecentrum, Pertsona Nagusiei buruzko Ikerketa Zentroa, Suedia), Kai Lechenring (Gizarte-politiken Ikerketarako Zentro Europarra, Austria), Gerdt Sundström (Gerontologia Institutua, Jönköping Unibertsitatea, Suedia), Hildegard Theobald (Vechta-ko Unibertsitatea, Alemania).
4 Beharrezkotzat jotzen dira higiene pertsonala, elikadura, ebakuazioa, mugikortasuna, oinarrizko osasun neurriak mantentzea (medikazioak hartu, sendagilearengana joan, etab.), etxeko garbiketak eta erosketak. 


\subsection{Balioztatze teoriko eta praktikoa}

Proiektuaren fase honen helburua izan da bermatzea, aukeraturiko tresna EAEko oinarrizko gizartelangileentzat baliagarria dela. Baliagarritasun hori frogatze aldera, lantalde bat sortu da, gure erkidegoko hamar udaletako hamabost gizarte-langile eta gizarte-ongizateko teknikarik, eta Araba eta Gipuzkoako Foru Aldundietako goi-teknikari banak ${ }^{5}$ osatua. Lantalde honen egitekoa bikoitza izan da:

Lehen fase batean, aukeraturiko tresnaren edukibaliotasuna aztertu du taldeak, hau da, zehaztu nahi izan da tresnak zenbateraino jasotzen duen benetan neurtu nahi den ezaugarria, alegia, etxez etxeko laguntzaren beharra. Fase hau 2010eko otsaila eta ekaina bitartean garatu da eta denbora horretan sei aldiz bildu da taldea proposaturiko tresnak aztertzeko. Azterketa honen ondorioz, taldeak tresnari zenbait aldaketa egitea proposatu du.

Balioztatzearen bigarren fasean, fase praktikoan, parte-hartzaileei aurreko fasean moldaturiko tresnak euren zerbitzuan frogatzeko eskatu zaie. Fase honen helburua izan da ikustea tresnak zenbateraino aurresan dezakeen profesionalen irizpidea etxez etxeko laguntza esleitu eta haren intentsitatea ezartzeko orduan. Horretarako, gizarte-langileei eskatu zaie zerbitzuaren eskaera egiten duen pertsona bakoitzari tresna aplikatzeko eta, aldi berean, beren irizpide profesionalean oinarrituz, pertsona horri zerbitzua emango lioketen ala ez zehazteko. Emaitza biak -tresnak emandakoa eta profesionalek zehaztutakoa- konparatuz, tresnaren aurresatebaliotasuna ezarri ahal izan da.

Tresnaren aurresate-baliotasuna aztertzeko ahalik eta laginik adierazgarriena lortzeari begira, EAEko udalen aniztasuna -eta zehazkiago, haien tamaina eta izaera landatarra edo urbanoa- ahalik eta ondoen islatuko zuten udalerriak aukeratu dira balioztatze fasean parte hartzeko, beti ere, kontutan hartuta parte hartu zezaketen udalen kopuruak mugatua izan behar zuela. Bestalde, tresnak erabiltzaile talde desberdinekin erabiltzeko lukeen balioa zehaztu ahal izateko, 282 kasuko lagina bildu beharko litzatekeela kalkulatu da, EAEn urtean jasotzen diren etxez etxeko laguntza eskaeren kopuruan oinarrituta. Jaso beharreko kasuak 1. Taulan zehazten den moduan banatu dira parte hartu duten hamar udalen artean. Banaketa hori, udalerri bakoitzaren biztanle kopuruaren arabera egin da.

${ }^{5}$ Beraien partaidetza eskertu nahi diegu honako pertsonei: Irune Aranburu (Eibarko Udala); Ana Contreras (Laudioko Udala); Marivi Udaeta (Santurtziko Udala); Loli Nadal, Mertxe Galindez, Consuelo Girón eta Ziortza Briñas (Vitoria-Gasteizko Udala); Marivi Etxeberria (Donostiako Udala); Karmele Guinea eta Sara Perez (Bilboko Udala); Leire Espinosa (Zuiako koadrila); Joana Larrauri (Mungialdeko Mankomunitatea); Itziar Morla, Igone Blanco eta Kitty Rebolledo (Getxoko Udala); Ana Lozano (Tolosako Udala); Estrella Gomara eta Ander Zapiain (Gipuzkoako Foru Aldundia); Francisco Castillo eta Elena Martin (Arabako Foru Aldundia); Lourdes Zurbanobeaskoetxea (Bizkaiko Foru Aldundia).
1. taula. Tresnaren balioztatze praktikorako aurreikusitako lagina

\begin{tabular}{l|c}
\hline Udal edo udal-elkargoa & Kasu kopurua \\
\hline Bilbo & 90 \\
\hline Mungialdeko mankomunitatea & 10 \\
\hline Zuiako koadrila & 10 \\
\hline Donostia-San Sebastián & 50 \\
\hline Eibar & 10 \\
\hline Vitoria-Gasteiz & 60 \\
\hline Getxo & 20 \\
\hline Laudio & 10 \\
\hline Santurtzi & 12 \\
\hline Tolosa & 10 \\
\hline Guztira & $\mathbf{2 8 2}$ \\
\hline
\end{tabular}

Iturria: Egilearen lana.

Balioztatze-fase honetan lorturiko emaitzak lantaldearen esku jarri dira eztabaidarako eta eztabaida honetan eginiko proposamenak baliatuz, azken moldaketak egin zaizkio tresnari. Momentu horretan, Eudelen esku jarri dira tresna eta balioztatze-ikerketaren txostena, hark dagokion ibilbidea eman diezaien. Eudelek tresna EAEko udalerri guztietara zabaltzea erabakiko balu, ezarpenfasearen urtebeteko jarraipena egingo du SIIS-ek tresna aplikatzeko orduan sortzen diren arazo edo zailtasunak bideratzeko.

\section{Emaitzak}

Ondorengo ataletan, tresnaren diseinu-fasean buruturiko ikerketaren emaitza nagusiak laburbilduko dira lehenik eta behin. Ondoren, aukeraturiko tresnen deskribapen laburra egingo da eta, azkenik, balioztatze-ikerketaren funtsezko emaitzak eskainiko dira.

\subsection{Etxez etxeko laguntza zerbitzua esleitzeko irizpideak Europako zenbait herrialdetan}

Buruturiko bilaketa dokumentalaren eta aipaturiko adituengandik jasotako informazioaren arabera, azterturiko herrialdeetan etxez etxeko laguntzazerbitzua esleitzeari dagokionez, egoera honakoa da:

Alemanian, Austrian, eta Frantzian, menpekotasuna aitortua duten pertsonek laguntza jasotzeko eskubidea dute. Eskubide hori onartze aldera, eskalak edo balorazio-tresnak garatu dituzte gobernuek. Gainontzeko pertsonek, irizpide horietan sartzen ez diren beharrak badituzte -gizarteratze-arazoak, esaterako-, laguntza jasotzeko aukera izan dezakete, tokian tokiko administrazioen irizpide eta baliabideen arabera. Zentzu honetan, herrialde horiena, gurean ematen denaren antzeko egoera litzateke.

Gainontzeko herrialdeetan -ipar Europan eta Erresuma Batuan-, etxez etxeko laguntza -menpekotasuna duten pertsonena, nahiz autonomoena- tokian tokiko administrazioen eskumena da, eta eurek ezartzen dituzte zerbitzua emateko irizpideak. 
Ingalaterran, zerbitzuen eskaintzan tokitik tokira ematen ziren aldeak ikusita, gobernuak Fair Access to Care (FACS) izenarekin ezagutzen diren irizpideak kaleratu zituen 2002an zaintza-zerbitzuetarako sarbidea arautzeko. Irizpide hauek, ordea, orokorregiak dira, eta ez dute balorazioa egiteko orduan kontuan izan beharreko alorrak -osasuna, eguneroko bizitza, harremanak, etab.- zehaztu baino egiten. Gainera, udal bakoitzaren esku gelditzen da erabakitzea, balorazioa egin ondoren, egoera larrian edo estuan dauden pertsonen beharrak bakarrik artatuko diren edo behar arinagoak dituztenei ere zerbitzua eskainiko zaien. Horrenbestez, ezin esan daiteke gobernuak neurri honekin lortu nahi zuen helburua lortu duenik.

Danimarkan ere gobernua saiatu da zaintza zerbitzuak eskatzen dituzten pertsonen beharrak baloratzeko irizpideak bateratzen. 2004an 'hizkuntza bateratua' izenarekin ezagutzen den tresna kaleratu zuen. Tresna horrek hiru atal ditu. Lehenengo atalean, pertsonaren beraren iritzia jasotzen da, dituen zailtasunei eta, bere ustez, behar duen laguntzari buruz. Bigarren atalean, berriz, eguneroko bizitzako jardueretan dituen zailtasunak neurtzeko eskala jasotzen da, beharren balorazio objektiboa egiteko. Azkenik, eskatzailearekin bizi diren pertsonek eskaini dezaketen laguntza zehazten du. Tresna hau zerbitzuen esleipenean nolabaiteko irizpideberdintasuna bermatzeko baliagarria izan daitekeen arren, berau erabiltzea udalentzat hautazkoa denez, orain arte ez ditu espero zitezkeen emaitzak lortu.

Laburbilduz, esan daiteke azterturiko zenbait herrialdetan etxez etxeko laguntza zerbitzua -eta gainontzeko zaintza-zerbitzu publikoak- emateko orduan aukera-berdintasuna bermatzeko ahaleginak egin direla. Hala ere, zuzenean estatuek ordaintzen dituzten menpekotasuna duten pertsonen arretarako sistemetan soilik lortu da, hein batean, helburu hori. Tokian tokiko administrazioen menpeko zerbitzuetan ez da lortu balizko erabiltzaileen beharrak baloratzeko prozesua bateratzerik.

\subsection{Tresna teknikoak}

Egindako bilaketaren bidez, EAEn etxez etxeko laguntza zerbitzua esleitu eta/edo eskaini beharreko intentsitatea ezartzeko balio dezaketen zenbait tresna aurkitu dira:

- Michigan Choice algoritmoa (MI-Choice).

- Ongoing Needs Identification Tool (ONI).

- Classification par Type en Milieu de Soins et Services Prolongés (CTMSP 87).

- Resident Assessment Instrument (RAI), bertsio suitzarra.

- Valutazione Integrata dei Tempi Asistenziali (VITA).

- Système de Mesure de l'Autonomie Fonctionnelle (ISO-SMAF).

- Resource Utilization Groups (RUG), etxerako bertsioa.

Tresna bakoitzari buruzko informazioa irakurri eta, ahal izan den kasuetan, tresna bera aztertu dute SIISeko teknikariek. Informazio hori baliatuz, aurkituriko tresna bakoitza EAEko etxez etxeko laguntzazerbitzuei zenbateraino egokitzen zaien aztertu da, metodologia atalean aipaturiko egiaztatze-zerrenda baliatuz (ikus 2. eta 3. Koadroak).

2. koadroa. Zerbitzuaren esleipena ebazteko tresna

\begin{tabular}{|c|c|c|c|c|c|c|}
\hline & MI-Choice & ONI & CTMSP 87 & VITA & ISO-SMAF & RUG-23 \\
\hline \multicolumn{7}{|l|}{ Ezinbesteko ezaugarriak } \\
\hline Pertsonaren autonomia du irizpide nagusi & + & - & + & - & + & + \\
\hline $\begin{array}{l}\text { Adineko pertsonekin eta ezintasunak dituzten } \\
\text { pertsonekin erabiltzeko garatu da }\end{array}$ & + & + & + & + & + & + \\
\hline $\begin{array}{l}\text { Oinarrizko gizarte-zerbitzuan, elkarrizketa bidez } \\
\text { aplikatzeko modukoa da (luzera, konplexutasuna eta } \\
\text { abarri dagokionez) }\end{array}$ & + & + & - & + & + & - \\
\hline $\begin{array}{l}\text { Gizarte-laneko gradua duten profesionalek bete ahal } \\
\text { izateko moduko tresna da }\end{array}$ & + & + & - & + & + & + \\
\hline \multicolumn{7}{|l|}{ Desiragarritzat jotzen diren ezaugarriak } \\
\hline Sinplea eta laburra da & + & + & - & + & + & - \\
\hline $\begin{array}{l}\text { Oinarrizko gizarte-zerbitzuetan dagoeneko jasotzen } \\
\text { den informazioa aprobetxatzen du }\end{array}$ & + & - & - & - & - & + \\
\hline $\begin{array}{l}\text { Gure zerbitzuetan erabiltzen diren beste tresna } \\
\text { batzuekin bateragarria da }\end{array}$ & + & - & - & - & - & + \\
\hline
\end{tabular}

Iturria: Egilearen lana. 


\begin{tabular}{|c|c|c|c|c|c|}
\hline & CTMSP 87 & $\begin{array}{l}\text { RAI-HC } \\
\text { (suitzarra) }\end{array}$ & VITA & ISO-SMAF & RUG-23 \\
\hline \multicolumn{6}{|l|}{ Ezinbesteko ezaugarriak } \\
\hline Pertsonaren autonomia du irizpide nagusi & + & + & - & + & + \\
\hline $\begin{array}{l}\text { Erabiltzailearen benetako beharrak hartzen ditu kontutan (laguntza } \\
\text { informala eta pribatua kontutan hartzeke) }\end{array}$ & + & + & + & + & - \\
\hline Beharren zuzeneko neurketan oinarritzen da & + & + & + & - & - \\
\hline $\begin{array}{l}\text { Pertsonak behar duen zuzeneko arreta-ordu kopurua neurtzen du } \\
\text { (joan-etorrietarako denbora kontutan izan gabe) }\end{array}$ & + & + & + & - & - \\
\hline $\begin{array}{l}\text { Gutxienez, arreta pertsonalerako eta etxeko zereginetarako behar } \\
\text { den denboraren artean bereizten du }\end{array}$ & + & + & + & - & - \\
\hline $\begin{array}{l}\text { Beharrezkotzat jotzen diren jarduera guztiak kontutan hartzen ditu, } \\
\text { eta horiek soilik }\end{array}$ & - & - & - & $\begin{array}{c}\text { Ez } \\
\text { dagokio }\end{array}$ & $\begin{array}{c}\text { Ez } \\
\text { dagokio }\end{array}$ \\
\hline \multicolumn{6}{|l|}{ Desiragarritzat jotzen diren ezaugarriak } \\
\hline Sinplea eta laburra da & - & - & + & + & - \\
\hline $\begin{array}{l}\text { Oinarrizko gizarte-zerbitzuetan dagoeneko jasotzen den } \\
\text { informazioa aprobetxatzen du }\end{array}$ & - & - & - & - & + \\
\hline $\begin{array}{l}\text { Gure zerbitzuetan erabiltzen diren beste tresna batzuekin } \\
\text { bateragarria da }\end{array}$ & - & - & - & - & + \\
\hline
\end{tabular}

Iturria: Egilearen lana.

Azterturiko tresnen konparaketa-koadroetan ageri denez, bai MI-Choice algoritmoak, bai ISO-SMAF tresnak, gurean erabiltzeko tresnarentzat ezinbestekotzat jotzen diren ezaugarri guztiak betetzen dituzte. Biak ere nazioarteko ospea duten ikerlari taldeek garatutakoak dira, eta euren jatorrizko herrialdeetan ikerketa zorrotzen bidez balioztatu dituzte. Gainera, euren erabilera ez da eremu zientifikora mugatu, aitzitik, praktikan balorazio tresna gisa erabilera praktikoa izan duten tresnak dira: SMAF tresna, Canadan epe-luzeko zaintza behar duten pertsonen beharrak neurtzeko erabiltzen den dimentsio anitzeko tresnaren parte da duela urte batzuetatik; MI-Choice tresna, berriz, Michigango estatuan etxeko zerbitzuak eskatzen dituzten pertsonen beharrak zehaztu eta horiek zerbitzu egokienetara bideratzeko erabili izan da urteetan.

Tresna bien arteko desberdintasun nagusia, beraz, desiragarritzat jotzen diren ezaugarri kopuruan datza. Etxez etxeko laguntza-zerbitzua eskatzen duten pertsonen beharrak zehazteko SMAF tresna aukeratzeak gure sisteman tresna berri bat sartzea suposatuko luke (menpekotasun egoera baloratzeko erabiltzen den BVD-a, eta Bizkaia eta Gipuzkoan Foru Aldundien baliabideetarako sarbidea arautzeko aukeratu den RAI tresnaz gain). Horrek zerbitzuetara sartzeko prozedura erabiltzaileentzat gaur egun dena baino ere oraindik konplikatuago egingo luke.

MI-Choice tresnak berriz, ondoren ikusiko den moduan, RAI metodoan oinarritzen denez, eta Gipuzkoa eta Bizkaiko Aldundiek beren zerbitzuetarako sarbidea arautzeko erabiltzen duten Screener Plus tresnan sartua dagoenez, tokian tokiko eta Foru Aldundietako administrazioetan egiten den balorazio prozesuari jarraitasuna eta koherentzia emango lioke eta dagoeneko balorazio zerbitzuetan jasotzen den informazioaren zati handi bat aprobetxatzeko aukera ematen du.

Aurreko guztia kontutan hartuz, EAEn etxez etxeko laguntza-zerbitzurako sarbidea arautzeko tresna egokiena MI-Choice algoritmoa dela ondorioztatu da eta berau erabiltzea proposatu zaio Eudeli.

Bestalde, zerbitzuaren intentsitatea neurtzeko tresnei dagokionez, taulak agerian uzten du aurkituriko tresnetatik batek ere ez dituela EAEko etxez etxeko laguntza-zerbitzuetan erabiltzeko tresnarentzat ezinbestekotzat jotzen diren baldintzak betetzen eta, ondorioz, tresna gure zerbitzuetarako bereziki garatzeko beharra dagoela adierazi zaio Eudeli. Aurrerantzean Tempo izendatuko dugun tresna hori garatzeko, RAI-aren bertsio suitzarra eta CTMSP kanadarra hartu dira oinarri.

\subsubsection{MI-Choice algoritmoa}

MI-Choice algoritmoa Michigango Unibertsitateko Gerontologia Institutuko ikerlari talde batek sortu zuen 2002an, Michigango Estatuko Administrazioaren eskariari erantzunez, eta interRAl baloraziotresnen familiako kide da. Algoritmo hori formula moduko bat da, familia bereko RAI-Home Care galdetegiko item kopuru txiki batean oinarrituz, baloratutako pertsonarentzat zerbitzurik egokiena zein den adierazten duena ${ }^{6}$. Orientabide hori bost zerbitzu-klase handitan eskaintzen du:

${ }^{6}$ MI-Choice algoritm oak RAI- Home Care galdetegiaren hirurehundik gora itemetatik, 30 baliatzen ditu balizko erabiltzaileentzat zerbitzurik egokiena zein den adierazteko. 
- Egoitza-zerbitzua (etxean jarraitzea komenigarria ez den kasuak bideratzen dira egoitza-zerbitzura).

- Etxeko laguntza pertsonal intentsiboa edo etxeko erizaintza-zerbitzua (egunero, hainbat oinarrizko jardueratarako laguntza behar duten pertsonentzako egokitzat jotzen dena).

- Etxeko laguntza pertsonal intermitentea (laguntzarik egunero behar ez dutenentzat, edo behar izanez gero, jarduera baterako soilik behar dutenentzat aproposa).

- Etxeko lanetarako laguntza (etxeko zereginetarako laguntza soilik behar duten pertsonentzako pentsatua).

- Informazio eta deribazioa (inolako zerbitzurik behar ez dutenentzat).

Zerbitzu-klase horiek nahiko ongi egokitzen zaizkio gure gizarte-zerbitzuen antolaketari. Bestalde, esan bezala, tresna honek gure zerbitzuetan erabiltzeko dituen abantailen artean aipatzekoak dira, datu enpirikoetan oinarrituz sortutakoa dela, Michiganen hainbat urtetan erabili dela zerbitzu komunitarioetarako sarbidea arautzeko edo gizarte-zerbitzuetan elkarrizketa bidez betetzeko moduko luzera duela, besteak beste.

\subsubsection{Tempo, zerbitzuaren intentsitatea neurtzeko tresna}

EAEn etxez etxeko laguntza-zerbitzuak erabiltzaile bakoitzari eskaini beharreko laguntza-orduen kopurua zehazteko garatu den tresna erabat intuitiboa da. Funtsean, eguneroko bizitzan egin beharreko jarduerak zehazten dituen zerrenda bat da, oro har, zeregin bakoitza burutzeko behar den denbora, eta epe jakin batean zeregin hori zenbat aldiz errepikatuko den zehazten duena7. Gizarte-langileak zerrenda horretan adierazi behar du zerbitzuaren eskaera egiten duen pertsonak zein jardueretan behar duen laguntza. Honenbestez, tresnak -hartarako prestaturiko aplikazio informatikoaren bitartezjarduera bakoitzari dagokion denbora gehitzen du.

Behin erabiltzaileak astean behar dituen laguntzaorduak zehaztuz gero, etxekoek eskaini diezaioketen laguntza zehaztu behar da, zeregin bakoitzean. Prozesu horretan, etxekoen partaidetza haientzat epe luzera eramangarri izan daitekeela ziurtatu behar du gizarte-langileak. Erabiltzaileak behar duen ordukopurua eta zaintzaile informalek eskaini diezaioketen kopuruaren arteko aldea da, printzipioz, etxez etxeko laguntza-zerbitzu publikoak eskaini beharrekotzat jotzen den intentsitatea.

\footnotetext{
7 Guztira 36 jarduera zehaztu dira katalogoan, 3 taldetan bilduta: arreta-pertsonaleko jarduerak (higienea, elikadura, mugikortasuna, eliminazioa eta nork bere osasunaren ardura) etxezaintza (garbiketak, erosketak, sukaldean egitea, gestioak, etab.) eta gizarte-heziketako jarduerak (higiene- eta osasun-ohituretan trebatzea, protesien erabileran trebatzea, jatekoa prestatzen erakustea, beste etxeko lan batzuek egiten erakustea edo etxeko tresnen erabileran trebatzea).
}

Emaitzetan, tresnak zehazten du erabiltzaileak astean beharko duen laguntza-orduen kopurua, aldi berean, jarduera pertsonaletarako, etxeko zereginetarako eta gizarte-heziketako jardueretarako beharko duenaren artean bereizten du. Baita ere, espero da, behin betiko tresna informatikoa garatzen denean, zerbitzua kudeatzen duten enpresei erabiltzaileen etxeetan egin beharreko jarduerak zehazteko zerrenda eman ahal izatea.

\subsection{Balioztatze-ikerketaren emaitzak}

Guztira, 2010eko ekaina eta 2011ko otsaila bitartean, 117 balorazio jaso dira parte hartu duten 10 udalerrietan, aurreikusitako kopurua baino askoz gutxiago, beraz. Udaletako gizarte-langileen partaidetza sustatu eta errazteko ahaleginak egin diren arren, -hala nola, tresnaren erabilerari buruzko prestakuntza sesio bereziak hala behar izan duten udalentzat, balorazioak tresna informatikoaren bidez ala eskuz betetzeko aukera, zalantzak sortu hala, haiek telefonoz argitzeko aukera, etab.- arrazoi desberdinak medio, ez da posible izan kopuru hori gehitzea, eta horrek asko murrizten du balioztatze-ikerketaren adierazgarritasuna. Hala eta guztiz ere, jasotako kasu-kopurua nahikoa izan da tresna erabiltzeko orduan sortu zitezkeen funtsezko arazoak antzemateko, eta, horiek konpontze aldera tresnari egin beharreko moldaketak proposatzeko.

\section{2. taula. Bildutako laginaren oinarrizko ezaugarri} sozio-demografikoak

\begin{tabular}{|c|c|c|c|}
\hline \multicolumn{2}{|c|}{ Ezaugarri sozio-demografikoak } & \multirow{2}{*}{$\begin{array}{c}\text { Abs. } \\
36\end{array}$} & \multirow{2}{*}{$\begin{array}{c}\% \\
30,8\end{array}$} \\
\hline \multirow{3}{*}{ Lurraldea } & Araba & & \\
\hline & Bizkaia & 51 & 43,6 \\
\hline & Gipuzkoa & 30 & 25,6 \\
\hline \multirow{5}{*}{ Adina } & 65 urte baino gutxiago & 8 & 6,8 \\
\hline & $65-75$ urte & 14 & 12,0 \\
\hline & $75-85$ urte & 51 & 43,6 \\
\hline & 85 urte edo gehiago & 42 & 35,9 \\
\hline & E.E. & 2 & 1,7 \\
\hline \multirow{4}{*}{$\begin{array}{l}\text { Menpekotasun } \\
\text { balorazioa }\end{array}$} & Autonomoa & 21 & 17,9 \\
\hline & Menpekotasuna duena & 58 & 49,6 \\
\hline & Balorazioa abian & 10 & 8,5 \\
\hline & Baloratzeke & 28 & 23,9 \\
\hline \multirow{4}{*}{ Bizikideak } & Bakarrik & 63 & 53,8 \\
\hline & Bikotearekin & 25 & 21,4 \\
\hline & Beste senide batzuekin & 22 & 18,8 \\
\hline & Beste egoera batzuetan & 7 & 6,0 \\
\hline \multicolumn{2}{|l|}{ Guztira } & 117 & 100,0 \\
\hline
\end{tabular}

E.E.: erantzunik ez.

Iturria: Egilearen lana. 
Zerbitzurako sarbidea arautuko lukeen MI-Choice tresnaren kasuan, tresnak zerbitzua jasotzeko aukera emango lioke ikerketan parte hartu duten pertsonen $\% 71,8$ ri: pertsona autonomoen $\% 61$,9ri eta menpekotasuna dutenen \%93,1-i, hain zuzen. Erabiltzaile hauei eskaini beharreko zerbitzuaren intentsitatea, berriz, astean 10 ordukoa litzateke, bataz beste, tresnaren irizpideen arabera: astean ia lau ordu pertsona autonomoei eta 13,5 ordu menpekotasuna dutenei.

3. taula. Aztertutako kasuetan, balioztaturiko tresnak ematen duen emaitza, zerbitzurako sarbidea eta haren intentsitateari dagokionez

\begin{tabular}{l|c|c}
\hline & $\begin{array}{c}\text { Etxez etxeko } \\
\text { laguntza jaso } \\
\text { dezakete (\%) }\end{array}$ & $\begin{array}{c}\text { Intentsitatea } \\
\text { bataz beste } \\
\text { (orduak } \\
\text { hilabeteko) }\end{array}$ \\
\hline Autonomoak & 61,9 & 15,5 \\
\hline Menpekotasuna dutenak & 93,1 & 54,3 \\
\hline Balorazioa abian dutenak & 80,0 & 43,9 \\
\hline Baloratzeke daudenak & 32,1 & 16,9 \\
\hline Lagin osoa & $\mathbf{7 1 , 8}$ & 39,8 \\
\hline
\end{tabular}

Iturria: Egilearen lana.

3. Taulan ageri denez, menpekotasuna onartua duten pertsonen \%6,9ak ez luke etxez-etxeko laguntza jasotzeko aukerarik izango MI-Choice tresnaren arabera eta emaitza hau desegokitzat hartu behar da, noski, Estatuko legeak pertsona hauei zerbitzua jasotzeko eskubidea onartzen dien neurrian.

Nolanahi ere, kontutan hartzekoa da datu absolutue$\tan 4$ kasu baino ez direla okerreko emaitza ematen dutenak eta horien proportzioa txikitzen joan dela analisirako kasu kopurua hazi ahala. 2011eko urrian, adibidez, guztira 62 kasu bilduta zeudenean, errore tasa \%8,8koa zen ${ }^{8}$. Horrek adierazten duena da, emaitza desegoki horien atzean balorazioa egiteko orduan buruturiko akatsak egon daitezkeela, edo ezaugarri bereziak dituzten pertsonei buruturiko balorazioak izan daitezkeela. Horrela balitz, okerreko emaitzen pisu erlatiboa txikitzen joango litzateke balorazio gehiago egin ahala.

Esan bezala, MI-Choice tresnak, etxez etxeko laguntza-zerbitzurako sarbidea irekitzeaz gain, pertsona bakoitzarentzat egokiena litzatekeen zerbitzu motari buruz orientabidea ere ematen du. Horri dagokionez, baloratutako kasuen erdia baino gehiago, \%52,1-a hain zuzen, arreta pertsonaleko etxeko zerbitzura bideratuko lituzke, \%9,4-a egoitza zerbitzuetan artatuak izateko egokiagotzat joko lituzke, eta \%10,2-ari etxeko lanetarako laguntzazerbitzua egokituko litzaioke.
3. grafikoa. Azterturiko kasuetan MI-Choice tresnak ematen duen orientabidea, zerbitzu motari dagokionez (\%)

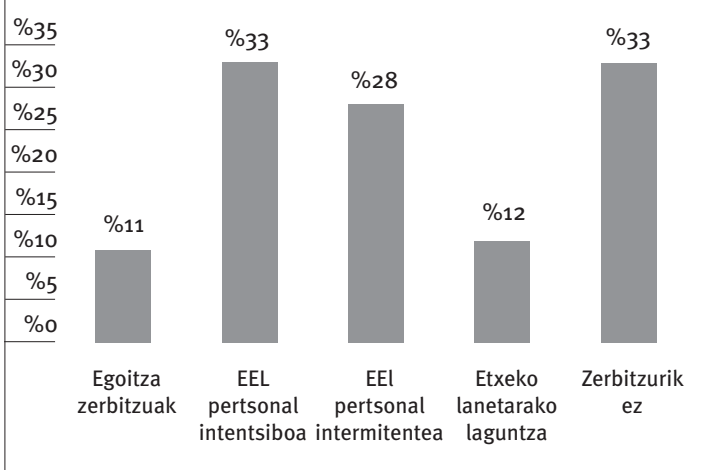

EEL: Etxez etxeko laguntza. Iturria: Egilearen lana.

\subsubsection{Emaitzen egokitasuna gizarte-langileen iritziz}

Gizarte-langileek egokitzat jotzen dituzte tresnaren emaitzak azterturiko kasuen $\% 79,8$ an, zerbitzurako sarbideari dagokionez, eta \%69an intentsitateari dagokionez. Kasu bietan, gainera, menpekotasuna duten pertsonekin lortzen diren emaitzak egokiagotzat jotzen dira pertsona autonomoekin lortzen direnak baino. Zerbitzurako sarbidea arautzeko tresnaren kasuan, menpekotasuna duten pertsonei egindako balorazioen \%94,3 hartzen dute gizartelangileek egokitzat, baina autonomoei egindakoen $\% 68,4$ besterik ez. Intentsitatea neurtzeko tresna aztertzean berriz, zifra horiek $\% 74,5$ eta $\% 66,7$ dira, hurrenez hurren.

4. taula. Azterturiko kasuen artean, gizarte-zerbitzuetako profesionalek egokitzat ematen dituzten balorazioak, menpekotasun-mailaren arabera (\%)

\begin{tabular}{l|c|c}
\hline \multirow{2}{*}{} & \multicolumn{2}{|c}{$\begin{array}{c}\text { Tresnaren emaitzari } \\
\text { egokia deritzozu? }\end{array}$} \\
\cline { 2 - 3 } & $\begin{array}{c}\text { Sarbidea } \\
\text { arautzeko } \\
\text { tresna } \\
(\mathbf{N}=\mathbf{1 0 4})\end{array}$ & $\begin{array}{c}\text { Intentsitatea } \\
\text { neurtzeko } \\
\text { tresna } \\
(\mathbf{N}=94)\end{array}$ \\
\hline Autonomoak & 68,4 & 66,7 \\
\hline Menpekotasuna dutenak & 94,3 & 74,5 \\
\hline Balorazioa abian dutenak & 88,9 & 62,5 \\
\hline Baloratzeke daudenak & 52,2 & 55,6 \\
\hline Lagin osoa & 79,8 & 69,0 \\
\hline
\end{tabular}

Iturria: Egilearen lana.

Bizitokiaren arabera ere desberdintasunak ageri dira gizarte-langileek egokitzat jotzen duten baloraziokopuruan. Zerbitzua jasotzeari begira, bikotearekin edo beste senideren batzuekin bizi diren pertsonei egindako hamar baloraziotatik bederatzi hartzen dira balekotzat, baina bakarrik bizi direnen $\% 68,5$ baino ez. Intentsitateari dagokionez, berriz, bikotearekin bakarrik bizi diren pertsonekin lortutako emaitzak
${ }_{8}^{8}$ 2011ko urriaren 8an, balioztatze praktikoaren jarraipena egiteko lantaldearekin buruturiko bilera batean, behin-behineko txosten bat aurkeztu zen, momentu hartan profesionalek bilduak zituzten 62 kasuekin lortutako emaitzak jasotzen zituena. 
4. grafikoa. Azterturiko kasuen artean, gizarte-zerbitzuetako profesionalek egokitzat ematen dituzten balorazioak, bizimoldearen arabera (\%)

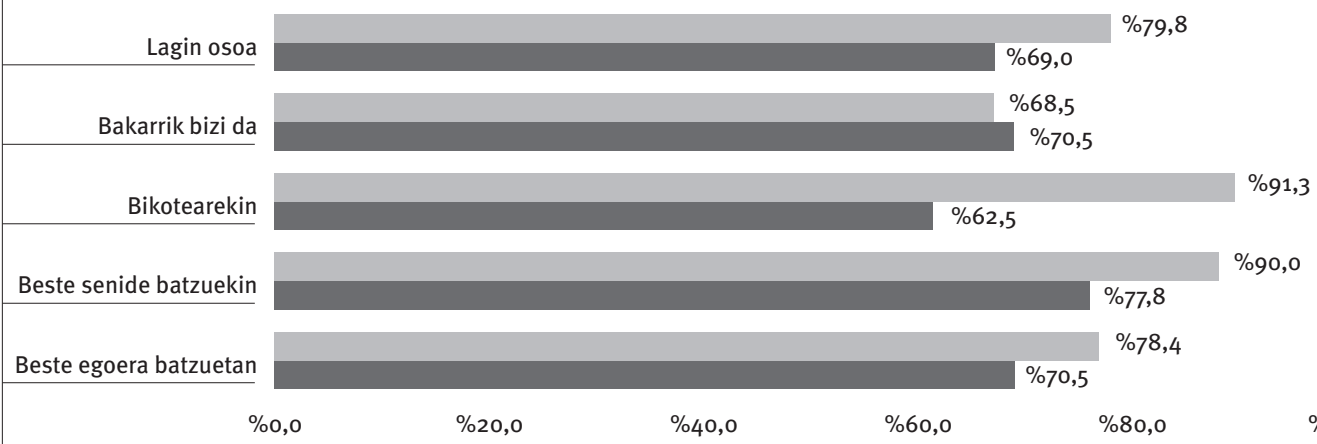

Sarbide arautzeko tresna

Intentsitatea neurtzeko tresna

Iturria: Egilearen lana.

dira kaskarrenak: bakarrik edo beste senitarteko batzuekin (oro har, seme-alabekin) bizi diren pertsonei egindako balorazioen \%7oetik gora dira egokiak gizarte-langileen ustez, baina senarra edo emaztea-

\subsubsection{MI-Choice tresnaren sentikortasuna eta zehaztasuna}

Ikerketa honen helburuetako bat, MI-Choice tresnaren aurresate-baliotasuna aztertzea izan da, tresnaren emaitzak ikerketaren fase praktikoan parte hartu duten profesionalen irizpideekin konparatuz. Horretarako, oro har, tresnaren emaitzen egokitasuna baloratzeko eskatzeaz gain, euren iritziz, baloraturiko pertsona bakoitzari etxez etxeko laguntzazerbitzua jasotzeko aukera eskaini beharko litzaiokeen adierazteko esan zitzaien gizartelangileei.

Profesionalek emandako 'urrezko estandar' hau tresnaren sentikortasuna eta zehaztasuna neurtzeko erabiliko da. Tresnaren sentikortasuna da, profesionalen irizpideen arabera zerbitzua behar duten pertsonak antzemateko duen ahalmena. Tresnaren zehaztasuna, berriz, zerbitzua behar ez duten pertsonei sarbidea eragozteko duen ahalmena izango da.

Definizio honetatik ondorioztatzen da, proba edo tresna bat oso sentikorra izan daitekeela eta aldi berean zehaztasun gutxikoa -hau da, behar egoeran dauden pertsona guztiei sarbidea emango lieke, baina baita zerbitzua behar ez duten pertsona askori ere (gaindiagnosia eginez)- edo alderantziz, oso zehatza baina sentikortasun gutxikoa izan daiteke, beharra duten pertsona asko zerbitzurik gabe utziz. Tresna on batek irizpide biak maximizatu beharko lituzke aldi berean.

4. koadroa. Kasuak sailkatzeko eskema

\begin{tabular}{|c|c|c|}
\hline $\begin{array}{l}\text { Zerbitzua jaso } \\
\text { dezake MI- } \\
\text { Choice tresnaren }\end{array}$ & \multicolumn{2}{|c|}{$\begin{array}{l}\text { Zerbitzua jasotzeko aukera izan behar luke } \\
\text { profesionalen arabera }\end{array}$} \\
\hline & $\mathrm{Ez}$ & Bai \\
\hline Ez & $\begin{array}{l}\text { Aurresate zuzena } \\
\text { (egiazko negatiboa) }\end{array}$ & $\begin{array}{l}\text { Aurresate okerra } \\
\text { (negatibo faltsua) }\end{array}$ \\
\hline Bai & $\begin{array}{l}\text { Aurresate okerra } \\
\text { (positibo faltsua) }\end{array}$ & $\begin{array}{c}\text { Aurresate zuzena } \\
\text { (egiazko positiboa) }\end{array}$ \\
\hline
\end{tabular}

Iturria: Egilearen lana.

Bildu diren 84 kasuekin $^{9}$ ez da posible sentikortasuna eta zehaztasuna fidagarritasunez aztertzea, izan ere, ez da jaso profesionalen ustez zerbitzutik kanpo gelditu behar lirateken kasu nahikorik eta, ondorioz, ezinezkoa da tresnaren zehaztasuna aztertzea. Nolanahi ere, oro har, \%71,4-ko adostasuna dago tresnaren emaitzen eta profesionalen irizpidearen artean.

Tresnaren emaitzak eta balioztatze praktikoan parte hartu duten udaletan erabiltzen diren irizpideak konparatuz lortzen den adostasun maila profesionalen iritzia aztertzean lortutakoaren antzekoa da, $\% 73,1$-koa hain zuzen. Gainera:

- Tresnaren sentikortasuna (egiazko positiboen tasa) \%74,5-ekoa da.

${ }^{9}$ Hogei kasutan ezin izan da jakin gizarte-langileak etxez etxeko laguntza zerbitzua baloratutako pertsonarentzat egoki kontsideratzen duen ala ez. 
- Tresnaren zehaztasuna (egiazko negatiboen tasa) askoz txikiagoa da, \%50ekoa. Hala eta guztiz ere, kontutan izan behar da, guztira, profesionalen iritziz zerbitzua jasotzeko beharrik ez luketen pertsonei dagozkien sei kasu besterik ez direla jaso eta, ondorioz, emaitza hau estimazio moduan ematen dela.

5. taula. Etxez etxeko laguntza zerbitzurako sarbidea MIChoice tresna eta gaur egun oinarrizko gizarte-zerbitzuetan erabiltzen diren irizpideen arabera

\begin{tabular}{l|c|c|c}
\hline $\begin{array}{l}\text { MI-Choice tresnaren } \\
\text { arabera, etxez etxeko } \\
\begin{array}{l}\text { laguntza zerbitzua } \\
\text { jasoko luke }\end{array}\end{array}$ & \multicolumn{3}{|l}{$\begin{array}{l}\text { Udalaren irizpideen arabera, etxez } \\
\text { etxeko laguntza zerbitzua jasoko luke }\end{array}$} \\
\hline & Ez & Bai & Guztira \\
\hline Ez & 3 & 25 & 28 \\
\hline Bai & 3 & 73 & 76 \\
\hline Guztira & 6 & 98 & 104 \\
\hline
\end{tabular}

Iturria: Egilearen lana.

Aukeraturiko tresnaren baliotasuna ezartzeaz gain, Ikerketaren fase praktiko honen beste helburuetako bat, tresna EAEko gizarte-langileen beharretara egokitzeko proposamenak burutzea zen, eta, horrenbestez, merezi du tresnaren emaitza desegokia den kasuen ezagugarriak aztertzea. Esan bezala, bi okerreko emaitza mota bereiz daitezke:

- Negatibo faltsuak: Profesionalen irizpideen arabera etxez etxeko laguntza behar duten pertsonak eta balioztatutako tresna erabiliz zerbitzutik kanpo geratuko liratekeenak. 23 kasu dira, honako ezaugarriak dituztenak:

- Gehienek euren menpekotasun egoera baloratzeke dute $(\% 65,2)$.

- Orokorrean bakarrik bizi dira (\%74).

- Gehienek etxeko zereginetarako zailtasunak dituzte, baina batek ere ez du bainurako zailtasunik (\%78).

- Gehienek ez dute erabaki sinpleak hartzeko zailtasunik (\%96).

- Positibo faltsuak, hau da, profesionalen iritziz zerbitzurik behar ez duten pertsonak baina tresnaren emaitzen arabera zerbitzua jaso ahal izango luketenak. Kasu bakar bat jaso da, normalean gizarte-langileek etxez etxeko laguntza-zerbitzua jasotzeko apropostzat hartzen dituzten pertsonen antzeko ezaugarriak dituena, berau (88 urteko emakumea, autonomoa baina etxeko lanetarako eta bere burua garbitzeko arazoak dituena, eta bakarrik bizi dena). Kasu honetan, beraz, profesionalaren irizpidea eta tresnaren arteko desadostasuna pertsonaren balorazioa egiteko orduan egindako akatsen bati zor dakioke, algoritmoaren emaitza desegoki bati baino gehiago.
3.3.3. Tempo, zerbitzuaren intentsitatea neurtzeko tresnaren emaitzen egokitasuna

Esan bezala, oro har, balioztatze praktikoan parte hartu duten profesionalek Tempo, etxez etxeko laguntza-zerbitzuaren intentsitatea neurtzeko garaturiko tresnak ematen dituen emaitzak egokitzat hartzen dituzte azterturiko kasuen \%69-an. Bestalde, tresnak ematen duen intentsitatea txikiegitzat jotzen dute 15 kasutan (\%18) eta gehiegizkotzat 11 kasutan (\%13).

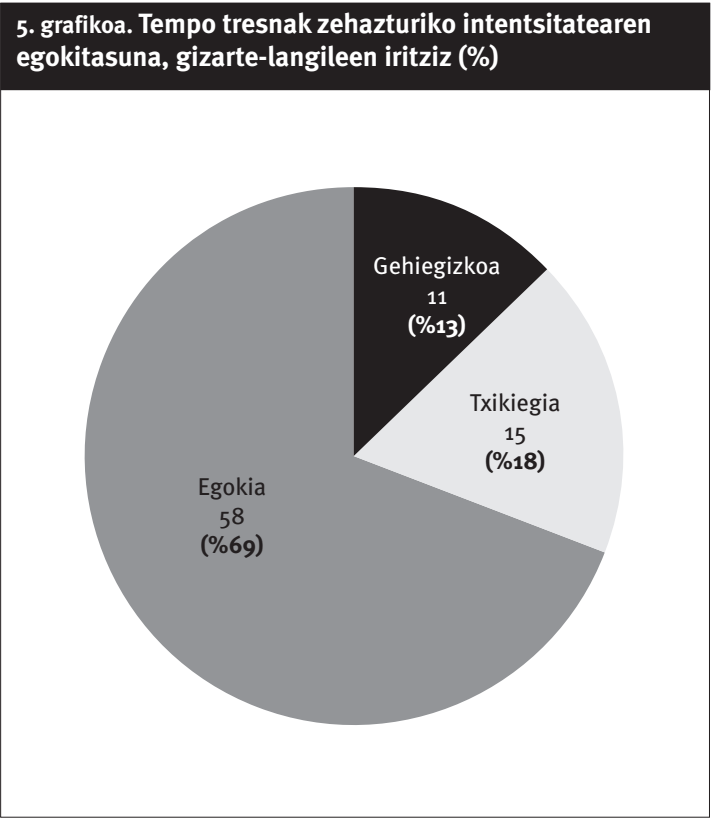

Menpekotasun mailaren arabera, tresnak adierazitako zerbitzuaren intentsitatea egokiagotzat jotzen dute profesionalek baloraturiko pertsonak menpekotasuna duenean $(\% 74,5)$, autonomoa denean baino $(\% 66,7)$. Bestalde egokitasun maila baxuenak baloratzeke dauden pertsonekin $(\% 62,5)$ eta balorazioa abian dutenekin ematen dira $(\% 55,6)$.

Azkenik, Tempo tresnaren katalogoan sartutako jardueren eta gizarte-langileek lortutako intentsitatearen egokitasunaz egiten duten balorazioaren artean harreman esanguratsuren bat ote zegoen ikusteko, Chi-karratu estatistikoa erabili da. Metodo honekin, lau jarduera antzeman dira, zeinetan, pertsonak laguntza beharra zuela adieraziz gero, lorturiko intentsitatea gizarte-langileen ustez gehiegizkoa baitzen. Jarduera horiek honakoak dira: bazkaldu edo afaltzeko laguntza, etxean ibiltzeko laguntza, bazkaria prestatzeko laguntza eta afaria prestatzeko laguntza. 
Bazkaldu/afaltzeko laguntza behar du

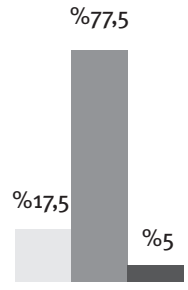

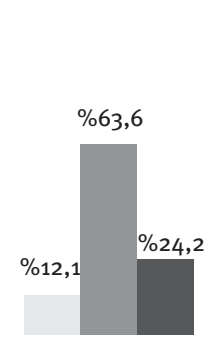

Bai

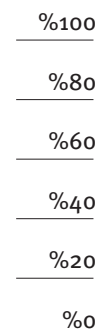

Bazkaria prestatzeko laguntza behar du

$$
\% 100
$$

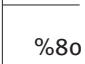

\begin{tabular}{|l}
$\% 80$ \\
\hline$\% 60$ \\
\hline
\end{tabular}

$\% 40$

$\% 20$

$\%$

Bazkaldu edo afaltzeko, etxe barruan ibiltzeko edo bazkaria edo afaria prestatzeko laguntza behar duten pertsonen kasuan, Tempo tresna erabiliz lortzen den zerbitzuaren intentsitatea gehiegizkotzat jotzen da baloratutako kasuen laurdena baino gehiagorentzat, kasu guztiak kontutan izanez gero, proportzio hori \%13-koa zen bitartean. Desberdintasun hauek estatistikoki esanguratsuak diren neurrian, tresna balioztatzeko eratutako lantaldeak jarduera horientzat hasiera batean emandako denbora eta maiztasuna aldatzea erabaki du.

\section{Ondorioak}

Jaso ahal izan den kasu-kopuru murritzak ezartzen dituen mugak kontuan hartuta, esan daiteke, oro har, ikertu den tresna baliogarria dela EAEko etxez etxeko laguntza-zerbitzua esleitu eta haren intentsitatea neurtzeari begira.

Tresnak emaitza onak lortzen ditu menpekotasuna duten pertsonen beharrak neurtzeko orduan (hamarretik bederatzi kasu baino gehiagotan emai-

Etxean ibiltzeko laguntza behar du

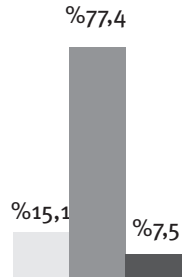

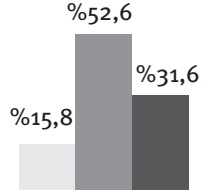

Bai

Afaria prestatzeko laguntza behar du

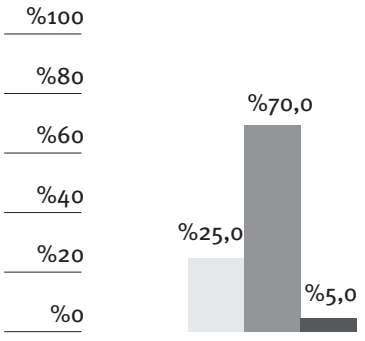

Ez

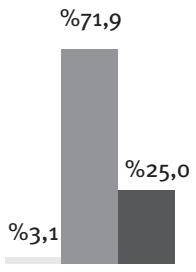

Bai tza egokia ematen du sarbideari dagokionez, eta hamarretik zazpitan, intentsitatea neurtzean), baina ez horrenbeste pertsona autonomoen kasuan. Hain zuzen, balioztatze-prozesuan parte hartu duten gizarte-langileen iritziz, tresnaren errurik nabarmenena da bakarrik bizi diren pertsona autonomoei, etxeko lanetarako laguntza soilik behar dutenean, ez diela zerbitzua jasotzeko aukerarik ematen. Honenbestez, tresna balioztatzeko bildutako aditutaldeak erabaki du tresnari moldaketak egitea, ezaugarri horiek dituzten pertsonei sarbidea emateko.

Era berean, ikerketaren bidez ezarri ahal izan da Tempo tresnaren katalogoan sartutako jarduera batzuek harremana dutela gizarte-langileen ustez gehiegizkoa litzatekeen emaitza batekin, alegia, jarduera jakin horietan laguntza behar dutela adieraziz gero, sarriagotan gertatzen dela tresnak ematen duen intentsitatea gehiegizkoa izatea. Honenbestez, lantaldeak jarduera horiei emandako denbora eta maiztasun balioak berrikusi eta aldatzea erabaki du, emaitza orokorrak euren irizpideetara hobeto egokitu daitezen. 
Moldaketa hauek egin ondoren, tresna eta balioztatze-txostena Eudelen esku ipini dira eta orain, udalen baitan dago tresnaren erabilerari buruz erabakitzea. Nolanahi ere, ikerketa honetan bildu ahal izan den kasu kopuru murritza kontutan hartuta, bertan parte hartu duen aditu-taldeak beharrezkotzat jo du, tresnaren erabilera udal guztietara hedatu aurretik, haren baliagarritasuna zalantzarik gabe ezartzeko ikerketa zabalago bat egitea. Froga horretan, kasu kopuru nahikoa bildu beharko litzateke, etxez etxeko laguntza-zerbitzuaren erabiltzaile izan daitezkeen populazio-talde desberdinei aplikatuz gero (ezintasunak dituzten pertsonak, buru gaixotasunak dituztenak, etab.), tresnak ze emaitza ematen dituen aztertzeko.

Azkenik, garaturiko tresnaren erabilera EAEko udal guztietara hedatzea erabakiko balitz, SIISeko teknikariek tresnaren erabileraren jarraipena egingo dute, urte betez, sortzen diren arazoak eta zailtasunak bideratzeko. 
(2003): Supplément Suisse au Manuel RAl-domicile, version 2.o. Manuel d'application de la méthode RAI-Domicile pour les Services à Domicile en Suisse, Paris, Editions de l'École Nationale de la Santé Publique.

ALEMANY, P. (2002): Instrumentos de valoración del programa de atención a domicilio, Valentzia, Societat Valenciana de Medicina Familiar i Comunitària [<http://www.svmfyc.org/grupos/ Publicaciones/ValorAD.pdf〉].

ASDO (2008): Étude perception par les usagers des outils d'évaluation des besoins de compensation de la perte d'autonomie, Caisse Nationale de Solidarité pour L'Autonomie [«http://www. cnsa.fr/IMG/pdf/2b.Rapport_ASDO_avec_les_ annexes.pdf>].

ASSOCIATION SUISSE DES SERVICES D’AIDE ET DE SOINS À DOMICILE (1998): Évaluation des besoins. Rapport final, Berna, Association Suisse des Services d'Aide et de Soins à Domicile.

BJÖRKGREN, M. A.; FRIES B. E.; eta SHUGARMAN, L. R. (2000): "A RUG-IIl case-mix system for home care”, Canadian Journal on Aging, 19. bol., 2. gehi., 106-125 or.

BRODSKY, J.; HABIB, J.; eta MIZRAHI, I. (2000): Long-Term Care Laws in Five Developed Countries. A Review, Ginebra, Osasunaren Mundu Erakundea [ http://whqlibdoc.who.int/hq/2000/WHO_ NMH_CCL_00.2.pdf)].

BUNTINX, F.; et al. (2004): "Options for a new procedure for determining care needs in Belgium: An initial exploration", Archives of Public Health, 62 zb., 173-184 or.

COLVEZ, A.; et al. (1997): “Analyser les pratiques pour construire un plan d'aide: une 'démarche qualité’ pour les services à domicile aux personnes âgées dépendantes", Revue Française des Affaires Sociales, zb. berezia, 283-298 or.

CONSEJERÍA DE TRABAJO Y POLIITICA SOCIAL (2001): Guía informativa del procedimiento del servicio de ayuda a domicilio para profesionales de los centros de servicios sociales, Murcia, Consejería de Trabajo y Política Social.

COUTTON, V. (2000): Les instruments médico-économiques fondés sur les groupes iso-ressources. Rapport réalisé pour la Direction de la Recherche, des Études, de l'Evaluation et des Statistiques, Paris, Ministère de l'Emploi et de la Solidarité.

CSONKA, A.; eta BOLL, J. L. (2001): Home Care in Denmark, in: MERMET E.; eta LEHNDORFF, S. (ed.), New Forms of Employment and Working Time in the Service Economy, Brusela, European Trade Union Institute [shttp://ec.europa.eu/research/ social-sciences/pdf/finalreport/soe2ct983078final-report.pdf>].

DEPARTMENT OF HEALTH (2002): The Single Assessment Process. Assessment Tools and Scales. Guidance, Londres, Department of Health [<http://207.61.67.46/GEIDEFile/instruments. PDF?Archive $=191225791940$ \& File $=$ instrumen ts_PDF>].

DIWAN, S.; et al. (1997): "Composition of the home care service package: Predictors of type, volume, and mix of services provided to poor and older people", The Gerontologist, 37. bol., 2. zb., 169-181 or.

DUBUC, N., HÉBERT, R.; eta DESROSIERS, J. (2004): “Les soins de longue durée aux personnes âgées: choix d'un système clinico-administratif dans le contexte d'un réseau de soins intégrés", Canadian Journal on Ageing, 23 bol., 1. zb., $35-45$ or. 
DUBUC, N.; RÉJEAN, H.; eta TOUSIGNANT, M. (2004): “Du développement à l'implantation des profils ISO-SMAF: une mise à jour", in: HÉBERT, R.; TOURIGNY, A.; GAGNON, M. (ed.), Intégrer les services pour le maintien de l'autonomie des personnes, Edisem, 177-206 [<http://www. medetic.com/docs/03/Prisma\%202004.pdf〉].

ENNUYER, B. (2006): Repenser le maintien à domicile: enjeux, acteurs, organisation, Paris, Dunod.

EVANS CUELLAR, A. E.; eta WIENER, J. M. (2000): “Can social insurance for long-term care work? The experience of Germany", Health Affairs, 19. bol., 3. zb., 8-25 or. [<http://content. healthaffairs.org/content/19/3/8.full.pdf〉].

FALEZ, F.; et al. (2007): “Étude comparée de trois échelles d'évaluation de la dépendance des personnes âgées en Belgique", La Revue de Gériatrie, 32. bol., 1. zb., 12-24 or.

FRIES, B. E.; et al. (2004): “Is telephone screening feasible? Accuracy and cost-effectiveness of identifying people medically eligible for home- and community based services", The Gerontologist, 44. bol., 5. zb., 680-688 or.

FRIES, B. E.; et al. (2002): "A screening system for Michigan's home- and community-based longterm care programs", The Gerontologist, 42. bol., 4. zb., $462-474$ or.

GARDENT, H. (2001): “Évaluer: avec quoi?”, Gérontologie et Société, 99. zb., 97-109 or.

GLENDINNING, C.; et al. (2004): Funding Long-Term Care for Older People. Lessons from other Countries, York, Joseph Rowntree Foundation [<http:// www.jrf.org.uk/sites/files/jrf/1859352065. pdf>].

HAMMAR, T.; et al. (2008): "Home-care clients' need for help, and use and costs of services", European Journal on Ageing, 5. bol., 147-160 or.

HARDY, J. P.; eta L'HUILLIER, J. M. (2008): L'aide sociale aujourd'hui, Issy-Les-Moulineaux, ESF Editeur.

HEALTH CANADA (1999): Provincial and Territorial Home Care Programs: A Synthesis for Canada, Health Canada [<http://publications.gc.ca/collections/ Collection/H88-3-30-2001/pdfs/other/hc_e. pdf>].

HÉBERT, R.; TOURIGNY, A.; eta GAGNON, M. (2004): Intégrer les services pour le maintien de l'autonomie des personnes, Quebec, Edisem [/http://www. medetic.com/docs/03/Prisma\%202004.pdf)].

HÉBERT, R.; et al. (2003): "Le système de mesure de l'autonomie fonctionnelle (SMAF)", La Revue de Gériatrie, 28. bol., 4. zb. [<http://expertisesante.com/modules/AxialRealisation/img repository/files/documents/SMAF_Revue $\% 20$ de\%20geriatrie\%202003.pdf〉].

HÉBERT, R.; et al. (2001): "Resources and costs associated with disabilities of elderly people living at home and in institutions", Canadian Journal on Aging, 20. bol., 1. zb., 1-19 or.

HIRDES, J. P.; et al. (1999): “Integrated health information systems based on the RAI/MDS series of instruments", Healthcare Management Forum, 12. bol., 4. zbk., 30-40 or.

HIRDES, J. P.; POSS, J. W.; eta CURTING-TELEGDI, N. (2008): "The method for assigning priority levels (MAPle): A new decision-support system for allocating home care resources", BMC Medicine, 6. bol., 9. zb. [khttp://www. springerlink.com/content/y27k5393lo74580o/ fulltext.pdf $\rangle$.

HUDSON, B.; HENWOOD, M. (2008): Analysis of Evidence Submitted to the CSCI Review of Eligibility Criteria. A Report Commissioned by CSCI for the Review of Eligibility Criteria, Londres, Commission for Social Care Inspection [rhttp://archive.cqc.org.uk/_db/ documents $/ 20080730 \% 20$ Tracked $\% 20$ FACS\%20Eligibility\%2oreview_typeset $1 \% 20$ v3\%20Dom.pdf s].

HUTTEN, J. B. F.; eta KERKSTRA, A. (ed.) [1996]: Home Care in Europe: A Country-Specific Guide to its Organization and Financing, Vermont, Ashgate.

KIPP, J.; et al. (2002): "Predicting in-home time of community care professionals", International Journal of Health Care Quality Assurance, 15. bol., 1. zb., 11-16 or.

LAGERGREN, M.; eta JOANSSON, P. A. (1998): "Are there differences in standard of care for the elderly? A comparative study of assistance decisions in Stockholm", Scandinavian Journal of Social Welfare, 7. bol., 340-349 or.

LARSSON, K. (2006): "Care needs and home-help services for older people in Sweden: Does improved functioning account for the reduction in public care?", Ageing and Society, 26. bol., 413-429 or.

LAUKKANEN, P.; et al. (2001): "Coping with activities of daily living in different care settings", Age and Ageing, 30. bol., 489-494 or.

LEICHSENRING, K. (2008): A Major Policy Impact of the European Centre's Consultancy: A New Long-term Care Scheme for Bolzano Alto Adige (Italy), saila: Policy Brief, European Centre [<http://www.euro.centre.org/ data/1201260830_78098.pdf)].

LEWINTER, M.; et al. (2004): "Developments in home help for elderly people in Denmark: The changing concept of home and institution", International Journal of Social Welfare, 13. zb., 89-96 or.

MAP (2005): Modèle d'accompagnement personnalisé. Guide pratique, Montigeon, Unapei [rhttp:// www.awiph.be/pdf/AWIPH/projets_nationaux/ logement/Outils/GuideMap2006.pdf`].

MDS (2006): Richtlinien der Spitzenverbände der Pflegekassen zur Begutachtung von Pflegebedürftigkeit nach dem XI. Buch des sozialgesetzbuches.

MEINOW, B.; KAREHOLT, I.; eta LAGERGREN, M. (2005): "According to need? Predicting the amount of municipal home help allocated to elderly recipients in an urban area of Sweden", Health and Social Care in the Community, 13. bol., 4 zb., 366-377 or.

MINISTÈRE DE LA SANTÉ ET DES SERVICES SOCIAUX (2003): Pour faire les bons choix. Chez soi: le premier choix. La politique de soutien à domicile, Quebec, Ministère de la Santé et des Services Sociaux [rhttp://publications.msss.gouv.qc.ca/ acrobat/f/documentation/2002/02-704-01. pdf $>$. 
- (2002): Outil d'Évaluation Multi Clientèle, Quebec, Ministère de la Santé et des Services Sociaux.

- (2000): Comité aviseur sur l'adoption d'un outil d'évaluation intégré des besoins des personnes en perte d'autonomie et de détermination des services requis notamment en institution ou à domicile, Quebec, Ministère de la Santé et des Services Sociaux [<http:// publications.msss.gouv.qc.ca/acrobat/f/ documentation/2000/00-703.pdf)].

MINISTÈRE DE LA SÉCURITÉ SOCIALE (2009): L'Assurance dépendance. Guide pratique, Luxenburg, Ministère de la Sécurité Sociale [<http://www. sante.public.lu/publications/remboursementsindemnites/assurance-dependance/assurancedependance-guide-pratique/assurancedependance-guide-pratique-fr.pdf`].

MINISTERIO DE TRABAJO Y ASUNTOS SOCIALES (1999): Vejez y protección social a la dependencia en Europa, Madrid, Ministerio de Trabajo y Asuntos Sociales.

MOYA, P.; et al. (2009): Costes asociados al cuidado informal en mayores dependientes del ámbito rural. Envejecer en Cuenca, Centro de Estudios Sociosanitarios. Universidad de Castilla-La Mancha.

OLAISON A.; eta CEDERSUND, E. (2006): “Assessment of home care: Negotiating solutions for individual needs", Journal of Aging Studies, 20. zb., 367380 or.

PAMPALON, R.; COLVEZ, A.; eta BUCQUET, D. (1991): "Établissement d'une table de passage de la dépendance des personnes âgées au besoin d'aide à domicile", Revue d'Epidémiologie et Santé Publique, 39 zb., 263-273 or.

PLYMOUTH COUNCIL (2005): Fair Access to Care Services. Practice Guidance (Revised), Plymouth, Plymouth Council [rhttp://www.plymouth.gov. uk/fair_access_to_care_services_-_practice_ guidance.pdf`].

POMMER, E.; WOITTIEZ, I.; eta Stevens, J. (2007): Comparing Care. The Care of the Elderly in Ten EUCountries, Haga, The Netherlands Institute for Social Research [khttp://www.scp.nl/english/ dsresource? objectid=21605\&type=org ].

POSS, J. W.; et al. (2008): "Validation of Resource Utilization Groups Version III for Home Care (RUG-III/ HC). Evidence from a Canadian Home Care Jurisdiction", Medical Care, 46. bol., 4. zb., 380-387 or.

ROBBINS D. (2008): Criteria for Care: Assessing Eligibility for Long-Term Care Services in Europe, Commission for Social Care Inspection; Social Care Institute for Excellence.

ROUSILLE, B. (2004): L'évaluation du handicap dans la perspective de la nouvelle prestation de compensation, saila: Rapport, 150. zb., Paris, Inspection Generale des Affaires Sociales [<http://lesrapports.ladocumentationfrancaise. $\mathrm{fr} / \mathrm{BRP} / 054000098 / 0000 . p d f$ )].

SUNDSTRÖM, G.; MALMBERG, B.; eta JOHANSSON, L. (2006): "Balancing family and state care:
Neither, either or both? The case of Sweden", Ageing and Society, 26 zb., 767-782 or.

SWEDISH ASSOCIATION OF LOCAL AUTHORITIES AND REGIONS (2007): Care of the Elderly in Sweden Today, Stockholm, Swedish Association of Local Authorities and Regions.

TARRICONE, R.; eta TSOUROS A. D. (ed.) [2008]: Home Care in Europe. The Solid Facts, Kopenhage, Osasunaren Mundu Erakundea.

THEOBALD, H. (2004): Care Services for the Elderly in Germany: Infraestructure, Access and Utilisation from the Perspective of Different User Groups, Berlin, Wissenschaftszentrum Berlin fur Sozialforschung [<http://bibliothek.wzb.eu/ pdf/2004/io4-302.pdf >].

TILQUIN, C. (1999): “Effets pervers associés aux modalités d'allocation des ressources aux organisations prenant en charge les personnes dépendantes. Apports d'un financement fondé sur la mesure des ressources requises individuellement EROS", Ruptures, 6. bol., 1. zb., 47-66 or. [〈http://www.medsp.umontreal.ca/ruptures/ pdf/articles/rup061_047.pdf)].

TILQUIN C.; eta COUPAL, M. (1997): CTMSP ‘87. La détermination des services requis et la mesure des ressources requis par le bénéficiaire, Quebec, EROS.

TIMONEN, V.; eta DOYLE, M. (2007): Home Care for Ageing Populations: A Comparative Analysis of Domiciliary Care in Denmark, the United States and Germany, Northhampton, Edward Elgar Publishing.

TOUSIGNANT, M.; et al. (2007): “Home-care programmes for older adults with disabilities in Canada: How can we assess the adequacy of services provided compared with the needs of users?", Health and Social Care in the Community, 15. bol., 1. zb., 1-7 or.

TOUSIGNANT, M.; et al. (2003): “Application of a case-mix classification based on the functional autonomy of the residents for funding long-term care facilities", Age and Ageing, 32. zb., 60-66 or.

TOUSIGNANT, M.; et al. (2003): Détermination du profil d'autonomie fonctionnelle et du taux de réponse aux besoins de la clientèle long terme du programme soutien à domicile des CLSC de Montérégie, Sherbrooke, Institut Universitaire de Gériatrie [rhttp://www.prismaquebec.ca/ documents/document/resumemonteregie. pdf〉].

VAN CAMPEN, C.; eta VAN GAMEREN, E. (2005): "Eligibility for long-term care in the Netherlands: development of a decision support system", Health and Social Care in the Community, 13. bol. [khttp://dx.doi.org/10.1186/1472-6963-11207)].

VAN RAAK, A.; et al. (ed.) [2003]: Integrated Care in Europe: Description and Comparison of Integrated Care in Six EU Countries, Maarssen, Elsevier. 